\title{
Genetic variability in the A microsatellite at $S L C 11 A 1$ gene and possible implications with innate resistance against brucellosis in Algerian native goats
}

\author{
HOSSEM SAHRAOUI ${ }^{1,2, \boldsymbol{*}, *}$, TOUFIK MADANI ${ }^{1}$, KHALED FANTAZI ${ }^{3}$, ASMA CHAOUCH KHOUANE ${ }^{2,4}$, \\ ABDELKADER AMEUR AMEUR ${ }^{5}$, PIETRO PASCHINO ${ }^{6}$, GIUSEPPE MASSIMO VACCA, \\ SEMIR BECHIR SUHEIL GAOUAR ${ }^{5, *}$, MARIA LUISA DETTORI ${ }^{6, *}$ \\ ${ }^{1}$ Department of Agronomy, University of Setif. El Bez, Sétif 19000, Algeria. "email: s_houss@yahoo.fr \\ ${ }^{2}$ National Center for Biotechnology Research. Nouvelle Ville Ali Mendjli, UV 03, Constantine 25016, Algeria \\ ${ }^{3}$ National Institute of Agronomic Research. 2 rue les frères OUADEK Hassen Badi, EL-Harrach, Algiers 16200, Algeria \\ ${ }^{4}$ Department of Agronomy, University of Biskra. Biskra 07000, Algeria \\ ${ }^{5}$ Department of Biology, University of Tlemcen. 22, Rue Abi Ayad Abdelkrim, Tlemcen, Algeria \\ ${ }^{6}$ Department of Veterinary Medicine, University of Sassari. Via Vienna, 2, Sassari 07100, Italy \\ *These authors contributed equally to this work
}

Manuscript received: 11 October 2020. Revision accepted: 17 November 2020.

\begin{abstract}
Sahraoui H, Madani T, Fantazi K, Chaouch Khouane A, Ameur Ameur A, Paschino P, Vacca GM, Gaouar SBS, Dettori ML. 2020. Genetic variability in the A microsatellite at SLC11A1 gene and possible implications with innate resistance against brucellosis in Algerian native goats. Biodiversitas 21: 5630-5636. Goat rearing is among the major agricultural activities practiced in Algeria. However, brucellosis represents an important threat to the goat sector and to public health. The aim of our work was to characterize the genetic variability of the A microsatellite at the 3' untranslated region (3' UTR) of SLCIIAl gene in Algerian native goat breeds as it was associated with Brucellosis genetic resistance in goat. Genomic DNA samples of 90 goats belonging to the four Algerian native breeds; Mekatia $(n=32)$, Arbia $(n=30)$, Dwarf of Kabylia $(n=14)$ and Mozabit $(n=14)$ have been analyzed. Polymorphism of region A microsatellite was determined by capillary electrophoresis identifying 8 alleles and 20 genotypes. Genetic parameters were also estimated. Polymorphic information content was PIC $=0.60$, the observed and the expected heterozygosity were Ho $=0.569$ and He $=$ 0.595 , respectively, and the values of $\mathrm{F}_{\mathrm{IS}}, \mathrm{F}_{\mathrm{IT}}$ and $\mathrm{F}_{\mathrm{ST}}$ were $0.044,0.064$, and 0.021 , respectively. The A microsatellite was highly polymorphic and alleles associated genetic resistance against brucellosis in other breeds or species have been identified. These results open a promising opportunity to implement a genetic improvement program to reduce goat brucellosis spread in Algeria.
\end{abstract}

Keywords: Brucellosis, disease innate resistance, genetic selection, polymorphism, native goat breeds, SLC11A1 gene

\section{INTRODUCTION}

Goat farming in Algeria is among the major practiced agricultural activities in harsh environments such as mountains, steppe, and Sahara (Belkahdem et al. 2014; Fantazi et al. 2017; Sahraoui et al. 2019). It is mainly associated with sheep and cattle and plays an important role for rural households in transforming pastoral resources into economic income and valuable nutritional sources; meat and milk. However, goat production is gradually shifting from pastoral low input systems to more economic systems to adapt to a new socio-economic context (Sahraoui et al. 2019). Goat population is estimated to 5 million and mainly composed of varied local breeds adapted to their environments. The most important are: Dwarf of Kabylia, Arbia, Makatia, and Mozabit. We can also find, depending on the region, products of crossbreeding with Maltese, Damascus, Murciana, Toggenburg, Alpine, and Saanen (Belkahdem et al. 2014; Tefiel et al. 2018). Knowledge of genetic resources is the first step towards rational conservation, management, and genetic improvement program.
Genetic resistance to intracellular pathogens was linked to a genomic region including the solute carrier family 11 member A1 (SLC11A1) gene, previously indicated as natural resistance-associated macrophage protein 1 (NRAMP1) (Capparelli et al. 2007), identified as a candidate gene. The SLC11Al has been studied in humans, laboratory animals, and livestock. It is $10.5 \mathrm{kbp}$ long, located in chromosome 2 (in cattle, sheep, and goat), and has 15 coding exons encoding a 571 amino acid long transmembrane protein (Ensembl, n.d.). The SLC11A1 protein is involved in the transport of divalent cations through the phagolysosome membrane, and it is thought to have a role in the response to bacterial infection (Thomas and Joseph 2012). A polymorphic microsatellite in the 3'UTR of the gene was associated with resistance to Brucella abortus in cattle (Martinez et al. 2010) and to Mycobacterium bovis infection in Zebu cattle (Kadarmideen et al. 2011).

In goats, the SLC11A1 3'UTR includes two GTn repeats flanked by similar sequences, which suggests a duplication event. The two GTn repeats were described as region A, ranging between 11 and 19 repeats, and region $\mathrm{B}$, ranging between 7 and 8 repeats (Liandris et al. 2009; Vacca et al. 
2011). The genotype of SLC11A1 region A has been reported to affect milk traits in Sarda goats (Piras et al. 2011). The GT8 allele of region $B$ has been associated with Mycobacterium avium subsp. Paratuberculosis (MAP) resistance/sensitivity (Korou et al. 2010; Liandris et al. 2009), and both regions A and B were associated with protection to Brucella melitensis infection (Iacoboni et al. 2014).

Brucellosis is a worldwide zoonotic infectious disease that has a significant economic impact in livestock farming and human public health. Caprine brucellosis remains a major problem in the Mediterranean region, the Middle East, Central Asia, sub-Saharan Africa, and Latin America (Rossetti et al. 2017). Mainly caused by Brucella melitensis, biovars 1 and 3 are the most frequently isolated in Mediterranean countries, and the main clinical manifestations are reproductive failure (i.e. abortion and birth of unthrifty offspring), orchitis, and epididymitis (Megid et al. 2014). In Algeria, the first description of brucellosis was made in 1907. Since then, it continues to rage in livestock farms, yearly causing heavy economic losses and thousands of human cases. However, since 1970 several control programs set up by the public authorities have reduced the rate of infection, particularly in cattle. However, prevalence of small ruminant brucellosis in the regions with high livestock density is still high $(5.2 \pm$ $0.8 \%$ ) (Lounes et al. 2011). Investigation was undertaken in Ghardaia (southern Algeria) observed that $8.2 \%$ of the goats were contaminated (Bachir Pacha et al. 2009), which hinders the development of the dairy and cheese goat value chain (Sahraoui et al. 2019). For practical, large-scale detection of Brucella-infected animals is carried out by serological tests.

Recommended caprine brucellosis control and eradication measures consist of vaccination combined with test-and-slaughter program (Blasco 2010). However, this strategy has many economic and management disadvantages (Iacoboni et al. 2014). A relatively new approach with great potential to control and eradicate diseases and improve health status of the herd is the selection of animals genetically resistant to pathogenic agents. This could be a promising tool to fight against Brucella infection (Iacoboni et al. 2014; Mapholi et al. 2016; Periasamy et al. 2014).

The aim of the present investigation was to characterize the genetic variability of the A microsatellite at $3^{\prime}$ untranslated region (3'UTR) of SLC11A1 in the four Algerian native goat breeds for a better knowledge on their genetic diversity and make comparisons with other breeds and species concerning an eventual genetic resistance potential against brucellosis.

\section{MATERIAL AND METHODS}

\section{Breeds, sampling strategy, and DNA extraction}

A total of 90 unrelated animals aged up to 12 months were chosen among 31 private herds for the study. These animals belonged to the four breeds reared in Algeria: Dwarf of Kabylia $(n=14)$ from the coastline and coastal highlands, Arbia $(\mathrm{n}=30)$ located in the steppe and northern Sahara (region of Tiaret, Djelfa, Biskra), Mekatia $(n=32)$ located in the region of Laghouat, and Mozabit $(n=14)$ located in the region of Ghardaia (Figure 1).

The main characteristics of the four Algerian native goat breeds are represented in Table 1.

Individual blood samples were collected from the jugular vein of each animal using vacutainer tubes containing K3EDTA.

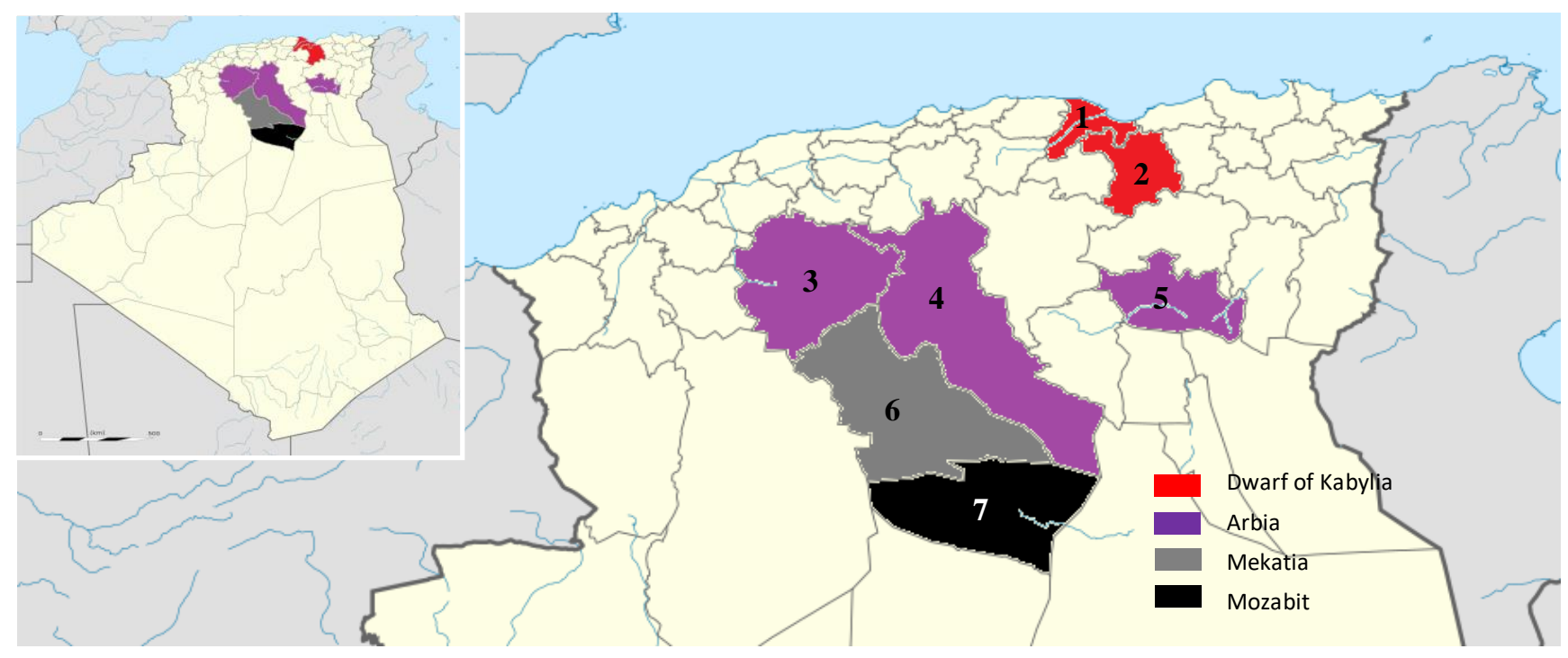

Figure 1. Representative distribution of the sampling sites of brucellosis in Algerian native goats. Note: 1. Bejaia, 2. Setif, 3 Tiaret, 4. Djelfa, 5. Biskr, 6. Laghouat, and 7. Ghardaia 
Table 1. Sample size and main characteristics of the four Algerian native goat breeds according to Kerba (1995)

\begin{tabular}{|c|c|c|c|c|c|c|c|c|c|c|}
\hline \multirow[b]{2}{*}{ Breed } & \multirow[b]{2}{*}{$\mathbf{N}$} & \multicolumn{2}{|c|}{ Height (cm) } & \multicolumn{2}{|c|}{ Weight (kg) } & \multicolumn{2}{|c|}{ Major purposes } & \multirow{2}{*}{$\begin{array}{l}\text { Hair } \\
\text { length }\end{array}$} & \multirow[b]{2}{*}{ Hair colors } & \multirow[b]{2}{*}{ Ears } \\
\hline & & Buck & Goat & Buck & Goat & $\begin{array}{c}\text { Milk } \\
\text { (liters) }\end{array}$ & $\begin{array}{c}\text { Meat } \\
\text { quality }\end{array}$ & & & \\
\hline Mekatia & 32 & 72 & 63 & 60 & 40 & 1 to 2 & Medium & Short & Grey, Brown & Long, Pending \\
\hline Arbia & 30 & 70 & 67 & 60 & 32 & 0.5 to 1 & Medium & Long & $\begin{array}{l}\text { Black, Grey, } \\
\text { Brown }\end{array}$ & $\begin{array}{l}\text { Long,Large, } \\
\text { Pending }\end{array}$ \\
\hline $\begin{array}{l}\text { Dwarf of } \\
\text { Kabylia }\end{array}$ & 14 & 68 & 55 & 60 & 47 & 0.5 to 1 & Appreciated & Long & $\begin{array}{l}\text { Black, } \\
\text { Brown }\end{array}$ & Long \\
\hline Mozabit & 14 & 68 & 65 & 50 & 35 & 2 to 2.5 & Medium & Short & Buff, Brown, Black & Long, Falling \\
\hline
\end{tabular}

\section{DNA isolation and genotyping}

Genomic DNA was extracted from blood leukocytes using the standard protocol of $\mathrm{NaCl}$ method (Miller et al. 1988). This step was conducted in the laboratory of Physiopathology and Biochemistry of Nutrition (University of Tlemcen). Quantification and qualification of DNA were performed using NanoDrop 2000 (Thermo Scientific, USA). DNA was then stored at- $20^{\circ} \mathrm{C}$ till further processing.

The SLC11A1 region A was PCR amplified using primers Fw1 5'-GTCTGGACCTGTCTCATCACC-3' and Rv1: 5'-ACTCCCTCTCCATCTTGCTG-3' (16) producing an amplicon of about 233 bp. Primer Fw1 was 5' labeled with the fluorescent dye 6-FAM (6-carboxyfluorescein). PCR was carried out in a total reaction volume of $25 \mu \mathrm{l}$ containing 1× PCR buffer, $1.5 \mathrm{mM} \mathrm{MgCl} 2,200 \mu \mathrm{M}$ dNTPs, $0.2 \mu \mathrm{M}$ of each primer and $0.5 \mathrm{U}$ of Taq DNA polymerase (Invitrogen $^{\mathrm{TM}}$ Platinum $^{\mathrm{TM}}$ Taq DNA Polymerase). Amplification reactions were performed with an initial denaturation step of $6 \mathrm{~min}$ at $94{ }^{\circ} \mathrm{C}$, followed by 35 cycles of $1 \mathrm{~min}$ at $94{ }^{\circ} \mathrm{C}, 45 \mathrm{~s}$ at $63{ }^{\circ} \mathrm{C}$ and $1 \mathrm{~min}$ at 72 ${ }^{\circ} \mathrm{C}$, with a final extension step of $15 \mathrm{~min}$ at $72{ }^{\circ} \mathrm{C}$. PCR products were evaluated in a $1.5 \%$ agarose gel electrophoresis and stained with SYBR® Green. Capillary electrophoresis was used for the separation of the PCR fragments labeled with fluorescent dye using ABI Prism 3730 DNA analyzer (Applied Biosystems), and two fragments of known length, obtained after cloning and sequencing (from (Vacca et al. 2011)), were used as an internal standard. Allele identification was performed using the Peak Scanner v.1.0 software.

\section{Statistical analysis}

Number of alleles per locus (Na), mean number of alleles (MNa), effective number of alleles $(\mathrm{Ne})$, observed heterozygosity (Ho), expected heterozygosity (He), average heterozygosity (H), Hardy-Weinberg equilibrium and Wright's F statistics $\left(F_{I T}, F_{I S}, F_{S T}\right)$, Nei gene diversity (Ht) and number of migrants per generation $(\mathrm{Nm})$ were calculated using GenAlEx (Peakall and Smouse 2012) while polymorphic information content (PIC) was calculated using Power Marker (V3.25).

XLSTAT software (V2014.5) has been used to calculate alleles' frequencies in the four studied breeds. Afterward, comparisons of allele and genotype frequencies with other studies have been performed to evaluate the possible genetic resistance of Algerian native goat breeds to brucellosis.

\section{RESULTS AND DISCUSSION}

\section{Genetic parameters}

A total of 8 alleles were detected in SLC11A1 region A GTn repeat in the goat population investigated. The effective number of alleles was $\mathrm{Ne}=2.655$. The microsatellite was highly informative with a mean PIC $=$ 0.60 , however, it ranged from 0.45 for $\mathrm{Dk}$ to 0.63 for Me. The observed, expected and unbiased heterozygosity were $0.569,0.595$, and 0.611 respectively. The values of $F_{I S}, F_{I T}$, and $F_{S T}$ for the overall population were $0.044,0.064$, and 0.021 respectively. The value of Nei gene diversity (Ht) was determined as 0.608 . The studied goat breeds showed a significant deviation from the Hardy-Weinberg equilibrium (HWE) for the microsatellite studied. The calculated gene flow $(\mathrm{Nm})$ value in the present study was considerably high (11.743) (Table 2).

Table 2. Genetic polymorphism parameters of the SLC11A1 region A microsatellite in the Algerian native goat breeds

\begin{tabular}{llllllllllllll}
\hline Breed population & & $\mathbf{N a}$ & $\mathbf{N e}$ & $\mathbf{N g}$ & $\mathbf{P I C}$ & $\boldsymbol{F}_{\boldsymbol{I S}}$ & $\boldsymbol{F}_{\boldsymbol{I} \boldsymbol{T}}$ & $\boldsymbol{F}_{\boldsymbol{S} \boldsymbol{T}}$ & $\mathbf{H o}$ & $\mathbf{H e}$ & $\mathbf{H W E}$ & $\mathbf{H t}$ & $\mathbf{N m}$ \\
\hline Overall population & 90 & 8 & 2.655 & 20 & 0.60 & 0.044 & 0.064 & 0.021 & 0.569 & 0.595 & $*$ & 0.608 & 11.743 \\
Mekatia & 32 & 7 & 2.934 & 12 & 0.63 & 0.099 & & & 0.594 & 0.659 & $*$ & & \\
Arbia & 30 & 7 & 2.663 & 11 & 0.59 & 0.253 & & & 0.467 & 0.624 & $*$ & & \\
Dwarf of Kabylia & 14 & 7 & 1.894 & 7 & 0.45 & -0.211 & & & 0.571 & 0.472 & $\mathrm{~ns}$ & & \\
Mozabit & 14 & 6 & 2.667 & 6 & 0.59 & -0.029 & & & 0.643 & 0.625 & $\mathrm{~ns}$ & & \\
\hline
\end{tabular}

Number of goats studied $(\mathrm{N})$, Number of alleles $(\mathrm{Na})$, effective number of alleles $(\mathrm{Ne})$, Number of genotypes (Ng), Polymorphic information content (PIC), Wright's F statistics $\left(F_{I T}, F_{I S}, F_{S T}\right)$, observed heterozygosity (Ho), expected heterozygosity (He), Average heterozygosity $(\mathrm{H})$, Hardy-Weinberg equilibrium, Nei gene diversity (Ht), Number of migrants per generation (Nm), Mekatia (Me), Arbia (Ar), Dwarf of Kabylia (Dk), Mozabit (Mo) 
$F_{I S}$ and $F_{I T}$ are a measure of the deviation of genotype frequencies from panmictic frequencies in terms of heterozygous deficiency or excess. Positive values indicate a deficiency of heterozygotes compared with the HWE expectation, while negative ones indicate an excess (Peakall and Smouse 2012). The heterozygote excess was observed in two populations (Dk and Mo) which have negative values. Obtained $F_{I T}$ value was close to 0 which means a high presence of heterozygous in the whole studied population. The $F_{S T}$ value in our study, estimated at 0.021 , maybe considered as low. Indeed, a value of 0 indicates no differentiation, while 1.0 indicates complete isolation. However, values comprised between 0.05 and 0.3 are typical for differentiation of livestock breeds (Lenstra et al. 2012). The values of heterozygosity, PIC, and number of alleles per locus supported high genetic variability of the SLC11A1 region A in Algerian native goat population. Genetic parameters such as PIC, Ho, and He in our study were higher than those in European and Chinese goat breeds ( $\mathrm{Ni}$ et al. 2019; Vacca et al. 2011) or in cattle (Hasenauer et al. 2013), which is interesting for the preservation of the genetic diversity. Mekatia (Me) and Mozabit (Mo) breeds had the highest values in terms of heterozygosity. Observed (Ho) and expected (He) heterozygosity values according to breeds were higher than those reported for some European goat breeds (Vacca et al. 2011). These results showed that this microsatellite used in Algerian goat breeds provide a high level of relevant information.

\section{Allele and genotype frequencies}

The number of GT repeats found in region A ranged from 10 to 18 for the eight identified alleles (GT12 was not revealed) with amplicon size range of 221 to $237 \mathrm{bp}$. The
231 bp allele (GT15) was the most abundant in the Algerian native goat population $(58.3 \%)$ while the $234 \mathrm{bp}$ allele (GT18) was less abundant (0.6\%). Comparison among Algerian breeds showed that the Dwarf of Kabylia was different from the other breeds as it was characterized by the absence of the allele GT16, the presence of the GT18, and the highest frequency of the GT15 (71.4\%) (Figure 2).

Korou et al. (2010) detected six alleles (GT13 to GT18) at SLC11A1 region A in Greek goats. In Sarda goat, Vacca et al. (2011) identified 8 alleles (GT11 to GT19 except for GT13), while Abraham et al. (2017) identified 8 alleles (GT10 to GT19 except for GT11 and GT13) in Kerala goat (India). Figure 3 shows that the allele GT10 detected in Algerian goat breeds was not detected in the other Mediterranean breeds (Vacca et al. 2011) but it was detected only in the Malabari breed in Kerala (Abraham et al. 2017) which is supposed to be a result of mixture between native breed and Arab breed (Jimcy et al. 2011), while the Algerian goats are similar to the Nubio-Syrian or Kurdish types (Ouchene-Khelifi et al. 2018). The GT12 allele was absent in Algerian as well as in Greek goats, while the GT13 allele was detected in these breeds, and was not detected in the other European breeds (Korou et al. 2010; Vacca et al. 2011). The GT18 was rare to absent in Algerian breeds as well as in the others.

The most frequent allele in the Algerian goats was GT15 (58.3\%), which was reported to have high frequencies also in Greek breeds (34\% to 39\%) (Korou et al, 2010; Taka et al, 2013). In the other EuroMediterranean breeds, it represents only 2.8, 3.9, 5.5, 1, and $5 \%$ in Sarda, Maltese, Sannen, Alpine, and Nubian, respectively, while it was absent in the MurcianoGranadina (Vacca et al. 2011).

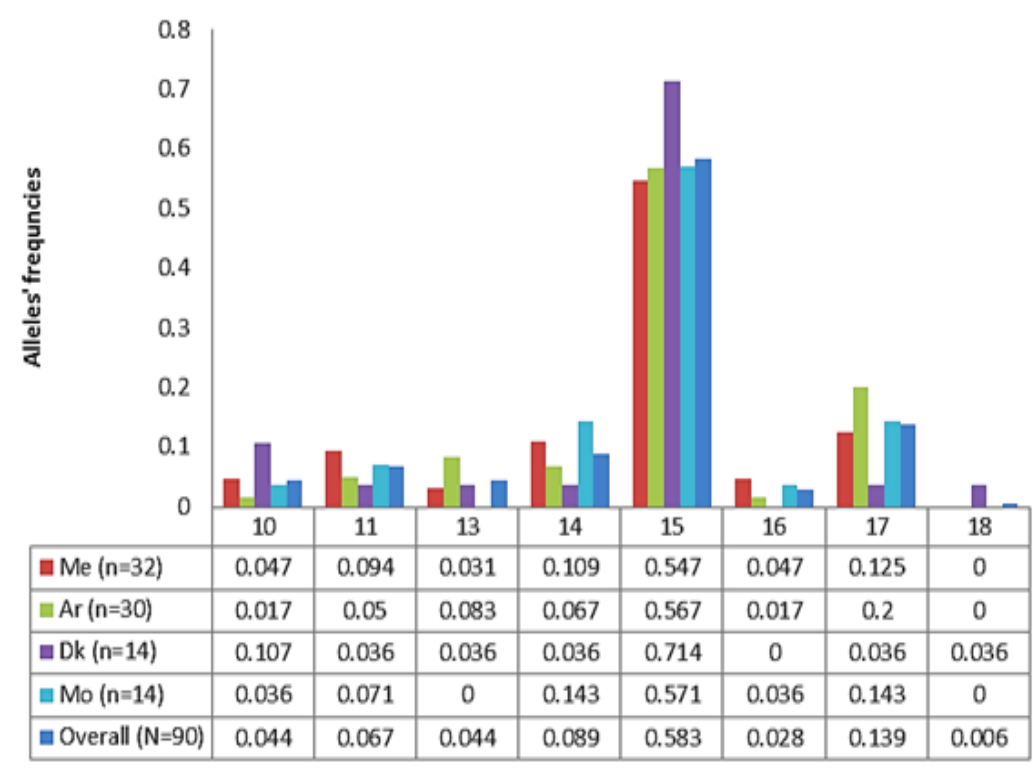

Figure 2. Allele frequencies by population at SLC11A1 region A microsatellite in the four Algerian native goat breeds. Note: Me: Mekatia, Ar: Arbia, Dk: Dwarf of Kabylia, Mo: Mozabit 


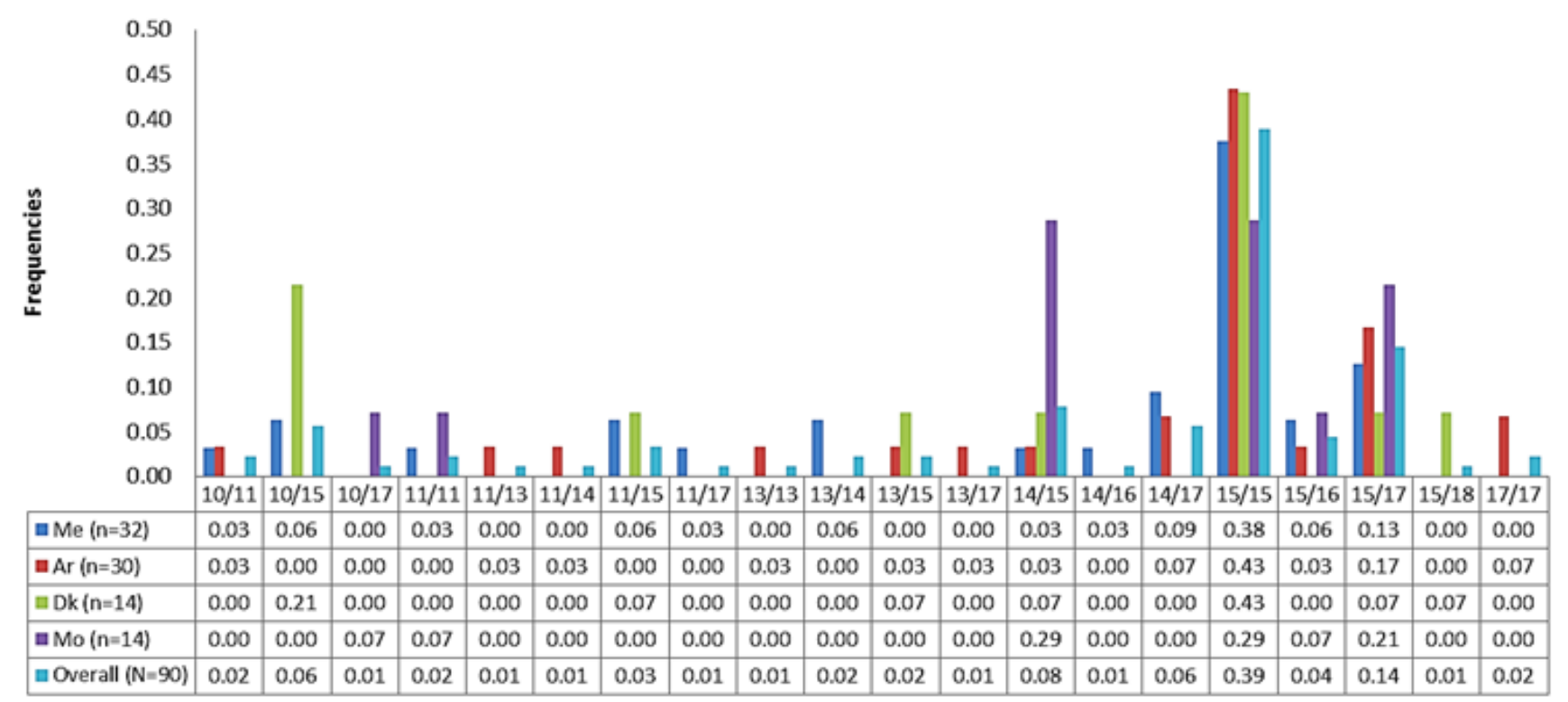

Figure 3. Comparison of allele frequencies of SLC11A1 region A microsatellite between Algerian and other goat breeds (16,18,19,40). Note: Me: Mekatia, Ar: Arbia, Dk: Dwarf of Kabylia, Mo: Mozabit

The GT15 represents respectively 5 and $12 \%$ in the Indian and in the Argentinian goat breeds (Abraham et al. 2017; Iacoboni et al. 2014). The GT16 allele displayed low frequencies in the analyzed population, while in the Indian breeds (Kerala) and Euro-Mediterranean breeds, it was the most frequent with values of $66 \%$ and $68.7 \%$, respectively (Abraham et al. 2017; Vacca et al. 2011). The GT16 is less represented in the Greek goat with only $39 \%$ of frequency (Korou et al. 2010), and in the Argentinian Creole crossbreed goats with $40 \%$ (Iacoboni et al, 2014). The GT16 represents only $2.8 \%$ in the Algerian goat with a maximum rate in Mekatia breed $(4.7 \%)$, but it was completely absent in Dwarf of Kabylia breed.

A total of 20 genotypes were observed. The genotype GT15/GT15 was the most frequent in Arbia, Dwarf of Kabylia and Mekatia breeds with 0.433, 0.429 and 0.375, respectively. While in Mozabit breed, it was represented by the same frequency as the genotype GT14/GT15 with a value of 0.286 . The most frequent genotypes in the whole population were GT15/GT15, GT15/GT17 and GT14/GT15 with $0.389,0.144$ and 0.078 , respectively (Figure 4).

In our study of region A at the 3'UTR of SLC11A1, 8 alleles constituting 20 genotypes have been identified. In the Argentinian goat, 21 genotypes constituted by only 6 alleles have been identified (Iacoboni et al. 2014) while the Euro-Mediterranean breeds present 26 genotypes formed from 9 alleles spread on 7 breeds (Korou et al. 2010; Vacca et al. 2011).

\section{Implications with innate resistance against brucellosis}

The number of GT repeats found in SLC11A1 region A ranged from 10 to 18 for the eight identified alleles constituting 20 polymorphic patterns. The most abundant allele in Algerian native goat populations was GT15 with the highest proportion in Dk breed, while the most abundant genotype was GT15/GT15. In the Argentinian goat, the association analysis between serological results and polymorphisms in region $\mathrm{A}$ indicated a significant association of the allele GT15 with absence of Brucellaspecific antibodies (Iacoboni et al. 2014). However, the study of region A in native Greek goats and the association of its polymorphism with innate resistance to paratuberculosis showed that none of the alleles identified were associated with resistance (Korou et al. 2010). The GT13 allele is less represented in the Algerian goat population as it represents only $4.4 \%$. This allele is absent in the Euro-Mediterranean breeds (Vacca et al. 2011) except in the Greek one representing $8 \%$. In cattle, the GT13 is the most frequent allele and represents in some breeds $100 \%$ of the population (Pazzola et al. 2009) and has been associated with resistance to brucellosis, while GT14 and GT15 have been associated with susceptibility (Barthel et al. 2001). 


\begin{tabular}{|c|c|c|c|c|c|c|c|c|c|c|}
\hline \multirow[t]{2}{*}{ 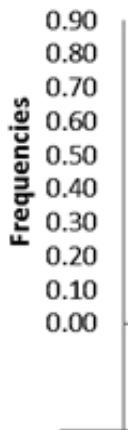 } & $\pi$ & & & & & & ] & & & \\
\hline & Algerian & Greek & Sarda & Maltese & Sannen & Alpine & $\begin{array}{l}\text { Murciano } \\
\text { Granadina }\end{array}$ & Nubian & $\begin{array}{l}\text { Argentinian } \\
\text { Creole } \\
\text { crossbred }\end{array}$ & Kerala \\
\hline$\square 10$ & 0.04 & 0.00 & 0.00 & 0.00 & 0.00 & 0.00 & 0.00 & 0.00 & 0.00 & 0.10 \\
\hline - 11 & 0.07 & 0.00 & 0.01 & 0.00 & 0.00 & 0.01 & 0.09 & 0.00 & 0.00 & 0.00 \\
\hline घ 12 & 0.00 & 0.00 & 0.04 & 0.02 & 0.05 & 0.01 & 0.09 & 0.13 & 0.00 & 0.02 \\
\hline a 13 & 0.04 & 0.08 & 0.00 & 0.00 & 0.00 & 0.00 & 0.00 & 0.00 & 0.11 & 0.00 \\
\hline घ 14 & 0.09 & 0.13 & 0.04 & 0.04 & 0.02 & 0.03 & 0.00 & 0.00 & 0.03 & 0.01 \\
\hline$=15$ & 0.58 & 0.34 & 0.03 & 0.04 & 0.06 & 0.01 & 0.00 & 0.05 & 0.12 & 0.05 \\
\hline$=16$ & 0.03 & 0.39 & 0.68 & 0.69 & 0.83 & 0.74 & 0.78 & 0.33 & 0.44 & 0.66 \\
\hline$\square 17$ & 0.14 & 0.04 & 0.15 & 0.00 & 0.06 & 0.21 & 0.02 & 0.18 & 0.08 & 0.04 \\
\hline$=18$ & 0.01 & 0.03 & 0.00 & 0.00 & 0.00 & 0.00 & 0.02 & 0.03 & 0.22 & 0.10 \\
\hline$\square 19$ & 0.00 & 0.00 & 0.05 & 0.22 & 0.00 & 0.00 & 0.00 & 0.27 & 0.00 & 0.02 \\
\hline
\end{tabular}

Figure 4. Genotype frequencies by population at SLC11A1 region A microsatellite in the four Algerian native goat breeds

In conclusion, $\mathrm{w}$ studied the genetic variability of the microsatellite located in region $A$ at the 3'UTR of the SLC11A1 gene in the four Algerian native goat breeds. It was highly polymorphic and alleles associated with genetic resistance against brucellosis in other breeds or species have been highlighted. The high polymorphism at region $\mathrm{A}$ indicates an opportunity to develop association studies between the alleles observed and the natural resistance against brucellosis, or other infectious diseases. Also, the high level of genetic variability is a promising opportunity to develop a genetic improvement program to use in addition to other classical brucellosis control and eradication measures. On the other hand, it would be interesting to study the genetic structure of the 3'UTR end of the SLC11Al gene in the foreign populations present in the country, since these breeds, in addition, to be increasingly reared by Algerian breeders mainly for milk production, are affecting the native populations through uncontrolled crossbreeding.

\section{REFERENCES}

Abraham A, Naicy T, Raghavan KC, Siju J, Aravindakshan T. 2017 Evaluation of the association of SLC11A1 gene polymorphism with incidence of paratuberculosis in goats. J Genet 96: 641-646. DOI: 10.1007/s12041-017-0820-9.

AnGR C. 2003. National Report on Animal Genetic Resources. Algeria [French].

Bachir Pacha M, Kechih S, Berber A, Yamani Triki R.R. 2009. An inquiry about ruminants epidemiologic brucellosis in some Algerian departments. Bull UASVM Vet Med 66: 370-375.

Barthel R, Feng J, Piedrahita JA, David N, Templeton JW, Adams LG, Barthel R, Feng J, Piedrahita JA, Mcmurray DN, Templeton JOEW, Adams LG. 2001. Stable Transfection of the Bovine NRAMP1 Gene into Murine RAW264.7 Cells : Effect on Brucella abortus survival. Infect Immun 69: 3110-3119. DOI: 10.1128/IAI.69.5.3110
Belkahdem S, Tefiel H, Belantar I, Chahbar M, Gaouar SBS. 2014. Discriminant analysis on the morphometry of local goats breeds in the western of Algeria. Gen Biodiv J 3 (2): 49-56.

Blasco J.M. 2010. Control and eradication strategies for Brucella melitensis infection in sheep and goats. Prilozi 31: 145-165.

Capparelli R, Alfano F, Amoroso M.G, Borriello G, Fenizia D, Bianco A, Roperto S, Roperto F, Iannelli D. 2007. Protective effect of the Nramp1 BB genotype against Brucella abortus in the water buffalo (Bubalus bubalis). Infect Immun. 75: 988-996. DOI: 10.1128/IAI.00948-06

Ensembl, n.d. Ensembl.org. URL https://www.ensembl.org/index.html.

Fantazi K, Tolone M, Amato B, Sahraoui H, Vincenzo di Marco L, La Giglia M, Gaouar SBS, Vitale M. 2017. Characterization of morphological traits in Algerian indigenous goats by multivariate analysis. Gene. Biodivers J 1: 20-30.

Hasenauer F.C, Caffaro M.E, Czibener C, Comerci D, Poli MA, Rossetti CA. 2013. Genetic analysis of the $3^{\prime}$ untranslated region of the bovine SLC11A1 gene reveals novel polymorphisms. Mol Biol Rep 40: 545552. DOI: 10.1007/s11033-012-2091-0.

Iacoboni P.A, Hasenauer F.C, Caffaro M.E, Gaido A, Rossetto C, Neumann R.D, Salatin A, Bertoni E, Poli M.A, Rossetti C.A. 2014. Polymorphisms at the 3' untranslated region of SLC11Al gene are associated with protection to Brucella infection in goats. Vet Immunol Immunopathol 160: 230-234. DOI: 10.1016/j.vetimm.2014.05.007.

Jimcy J, Raghavan KC, Sujatha KS. 2011. Diversity of local goats in Kerala, India , based on morpho-biometric traits. Livest Res Rural Dev 23: 19. www.lrrd.org/lrrd23/5/jimc23119.htm

Kadarmideen HN, Ali AA, Thomson PC, Muller B, Zinsstag J. 2011. Polymorphisms of the SLC11Al gene and resistance to bovine tuberculosis in African Zebu cattle. Anim Genet 42: 656-658. DOI: 10.1111/j.1365-2052.2011.02203.x.

Kerba A. 1995. Base de données sur les races caprines en Algérie. FAO, Rome. [French]

Korou L.M, Liandris E, Gazouli M, Ikonomopoulos J. 2010. Investigation of the association of the SLC11A1 gene with resistance/sensitivity of goats (Capra hircus) to paratuberculosis. Vet Microbiol 144: 353358. DOI: 10.1016/j.vetmic.2010.01.009.

Lenstra JA, Groeneveld .F, Eding H, Kantanen J, Williams JL, Taberlet P, Nicolazzi EL, Sölkner J, Simianer H, Ciani, E, Garcia JF, Bruford MW, Ajmone-Marsan P, Weigend S. 2012. Molecular tools and analytical approaches for the characterization of farm animal genetic diversity. Anim Genet 43: 483-502. DOI: 10.1111/j.13652052.2011.02309.x 
Liandris E, Gazouli M, Ikonomopoulos J. 2009. Characterization of the caprine (Capra hircus) SLC11A1 gene: innate resistance to paratuberculosis Liandris. Online J Vet Res 13: 41-52.

Lounes N, Adaika B, Hamidatou H, Bouyoucef A, Garin-Bastuji B. 2011 Enquête préliminaire sur la brucellose cameline dans la région d'El Oued, in: 4èmes Journées Vétérinaires de Blida 28-29 Novembre 2011, Faculté Des Sciences Agrovétérinaires, Université de Blida, Algérie.

Mapholi N.O, Maiwashe A, Matika O, Riggio V, Bishop S.C, MacNeil M.D, Banga C, Taylor J.F, Dzama K. 2016. Genome-wide association study of tick resistance in South African Nguni cattle. Ticks Tick Borne Dis 7: 487-497. DOI: 10.1016/j.ttbdis.2016.02.005

Martinez R, Dunner S, Toro R, Tobon J, Gallego J, Canon J. 2010. Effect of polymorphisms in the SLC11A1 coding region on resistance to brucellosis by macrophages in vitro and after challenge in two Bos breeds (Blanco Orejinegro and Zebu). Genet Mol Biol 33: 463-470. DOI: $10.1590 /$ S1415-47572010000300014

Megid J, Antonio Mathias L, A. Robles C. 2014. Clinical manifestations of Brucellosis in domestic animals and humans. Open Vet Sci J 4: 119-126. DOI: 10.2174/1874318801004010119

Miller S.A, Dykes D.D, Polesky H.F. 1988. A simple salting out procedure for extracting DNA from human nucleated cells. Nucleic Acids Res 16: 1215. DOI: 10.1093/nar/16.3.1215.

Ni WW, Ee GX, Basang WD, Huang Y.F 2019. Molecular variant estimation of SLC11A1 related microsatellites in Chinese indigenous goats. Russ J Genet 55: 993-999. DOI: 10.1134/S102279541908009X.

Ouchene-Khelifi N.A, Lafri M, Pompanon F, Ouhrouch A, Ouchene N, Blanquet V, Lenstra JA, Benjelloun B, Silva A Da. 2018. Genetic homogeneity of North-African goats. PLoS One 13: e0202196. DOI 10.1371/journal.pone.0202196.

Pazzola M, Dettori M.L, Atzeni M, Balia F, Vacca G.M. 2009. Genetic diversity of NRAMP1 3'-UTR microsatellite in cattle breeds reared in Sardinia. Ital J Anim Sci 8: 126-128.

Peakall R, Smouse P.E. 2012. GenALEx 6.5: Genetic analysis in Excel. Population genetic software for teaching and research-an update. Bioinformatics 28: 2537-2539. DOI: 10.1093/bioinformatics/bts460
Periasamy K, Pichler R, Poli M, Cristel S, Cetrá B, Medus D, Basar M, Thiruvenkadan AK, Ramasamy S, Ellahi MB, Mohammed F, Teneva A, Shamsuddin M, Podesta MG, Diallo A. 2014. Candidate gene approach for parasite resistance in sheep-Variation in immune pathway genes and association with fecal egg count. PLoS One 9: e0088337. DOI: 10.1371/journal.pone.0088337.

Piras G, Pazzola M, Balia F, Pira E, Dettori M.L, Carcangiu V, Vacca G.M. 2011. Polymorphism of caprine SLC11A1 gene and relationships with hygienic characteristics of milk. Agric Conspec Sci 76: $175-178$.

Rossetti CA, Arenas-Gamboa AM, Maurizio E. 2017. Caprine brucellosis: A historically neglected disease with significant impact on public health. PLoS Negl Trop Dis 11: e0005692. DOI: 10.1371/journal.pntd.0005692.

Sahraoui H, Mamine F, Madani T. 2019. Goat value chain in Algeria, sustainable development proposals to cope with changes. In: Ruiz R, López-Francos A, López Marco L (eds). Proceedings of the 2nd Joint Seminar on Innovation for Sustainability in Sheep and Goats. Zaragoza, Spain, 3-5 October 2017.

Taka S, Liandris E, Gazouli M, Sotirakoglou K, Theodoropoulos G, Bountouri M, Andreadou M, Ikonomopoulos J. 2013. In vitro expression of the SLC11A1 gene in goat monocyte-derived macrophages challenged with Mycobacterium avium subsp paratuberculosis. Infect Genet Evol 17: 8-15. DOI: 10.1016/j.meegid.2013.03.033.

Tefiel H, Ata N, Chahbar M, Benyarou M, Fantazi K, Yilmaz O, Cemal I, Karaca O, Boudouma D, Gaouar SBS. 2018. Genetic characterization of four Algerian goat breeds assessed by microsatellite markers. Small Rumin Res 160: 65-71. DOI: 10.1016/j.smallrumres.2018.01.021.

Thomas N, Joseph S. 2012. Role of SLC11A1 gene in disease resistance. Biotechnol Anim Husbandry Biotehnologija u Stoc 28: 99-106. DOI: 10.2298/bah1201099t.

Vacca GM, Pazzola M, Pisano C, Carcangiu V, Diaz M.L, Nieddu M, Robledo R, Mezzanotte R, Dettori M.L. 2011. Chromosomal localisation and genetic variation of the SLC11A1 gene in goats (Capra hircus). Vet J 190: 60-65. DOI: 10.1016/j.tvj1.2010.09.028 